\title{
An adaptive thermal comfort model for naturally ventilated classrooms of technical institutions in Madurai
}

\author{
Subhashini S. \\ Department of Architecture, Thiagarajar College of Engineering, Madurai, India \\ Thirumaran Kesavaperumal \\ Department of Architecture, National Institute of Technology Tiruchirappalli, \\ Tiruchirappalli, India, and \\ Masa Noguchi \\ ZEMCH EXD Lab, Faculty of Architecture, Building and Planning, \\ The University of Melbourne, Melbourne, Australia
}

\begin{abstract}
Purpose - Occupants dwelling in hot climatic regions of India for a longer term are tolerable to high temperature levels than predicted by American Society of Heating, Refrigerating and Air-Conditioning Engineers (ASHRAE) standards. The purpose of this study is to evaluate the thermal sensations (TS) and neutral temperature of the occupants in naturally ventilated (NV) and air-conditioned (AC) classrooms of two technical institutions located in the same premises in the suburbs of Madurai. The main focus of this study is to understand the occupants' behaviour in response to the thermal conditions of the educational buildings particularly in the warm and humid climatic zone of Madurai.

Design/methodology/approach - This research collected data through field studies. The data included 383 survey questionnaires from NV classrooms and 285 from AC classrooms, as well as on-site measurements of interior and exterior weather conditions. The TS results show that the students preferred well-designed NV classrooms than AC classrooms. A new adaptive comfort equation derived from this study can be applied to $\mathrm{NV}$ classrooms in warm and humid climates where mean outdoor temperature exceeds $40^{\circ} \mathrm{C}$.

Findings - The neutral temperature derived for NV classrooms in Madurai ranged from $29^{\circ} \mathrm{C}$ to $34^{\circ} \mathrm{C}$. Thus, the occupants in the NV classrooms of the higher learning educational institutions in the warm and humid climatic region of Madurai can adapt well to higher indoor temperature levels than predicted by ASHRAE comfort levels with minimum adjustments.

Research limitations/implications - The study was limited to only occupants in two premier higher learning technical educational institutions located in Madurai region within 5-10 km within the city limits to understand the implications of microclimate with respect to the urban context. Thus, further research is required to examine the tendency under local conditions in other regions beyond those applied to this study.

Social implications - The findings of this study showed that occupants in higher learning educational intuitions in Madurai prefer NV classrooms than AC classrooms. Therefore, with rising demands of energy use for mechanical ventilation and the associated high cost for running $\mathrm{AC}$ buildings, architects should prioritize the design of energy efficient buildings through the optimal use of passive design strategies for ventilation and thermal comfort. This study gives a base data for architects to understand the adaptive
\end{abstract}

The authors would like to acknowledge architect Ponni. G, a former under graduate student of Thiagarajar College of Engineering, Madurai, Tamilnadu, India for her interest and support towards questionnaire survey and data collection.

Open House International (c) Emerald Publishing Limited C Emerald Publishing Limited DOI 10.1108/OHI-03-2021-0075
Received 28 March 2021 Revised 20 April 2021 Accepted 20 April 2021

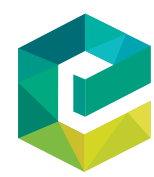

Adaptive comfort model

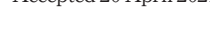


limitations of occupants and design NV buildings that can promote natural ventilation and provide better thermal environments that can help increase the productivity of students.

Originality/value - This paper was an attempt to develop the adaptive comfort model for NV classrooms in Madurai regions. There has been no attempt to identify the adaptive comfort levels of occupants in higher learning technical educational institutions located in warm and humid climatic region of India.

Keywords Thermal sensation, Adaptive comfort, Classrooms, Natural ventilation, Occupant behaviour, Warm and humid climate, Built environment tectonics and technologies, Neutral temperature

Paper type Research paper

\section{Introduction}

India is a country with different climatic conditions ranging from scorching summers to extremely cold winter conditions. Over the period 1970 till present day, research on climate studies of India has identified a decrease in the frequency of cold nights across India and an increase in the number of warm nights and hot days (IPCC, 2011). A rise of about $2^{\circ} \mathrm{C}-4^{\circ} \mathrm{C}$ across India is expected by the end of the 21 st century as per the reports published by the National Intelligence Council (NIC, 2009). On the other hand, energy demands all over India has been rising tremendously since 2000 because of the rapid growth in urbanisation in cities. Research reveals that energy demand in India has raised from $4.4 \%$ in 2000 to $5.7 \%$ in 2013 and is liable for almost $10 \%$ of the rise in global energy demand since 2000 (Energy Statistics, 2017). Thus buildings in the future have to be designed in such a way that they can cater their energy needs for heating and cooling through passive systems.

Natural ventilation is one of the important passive systems for indoor air quality and thermal comfort. Improper ventilation in classrooms can create uncomfortable conditions such as heat stress to the occupants in NV classrooms (Subhashini and Thirumaran, 2018). It has also been observed that it is a challenging task to achieve thermal comfort in naturally ventilated (NV) space due to lower air velocity. The high temperature levels and low air supply rates are the main reasons for the increase in carbon dioxide levels in classrooms (Zomorodian et al., 2016). Hence, it requires appropriate planning strategies and efficient design of the building envelope to prevent heat gains into buildings and promote natural ventilation.

This paper aims at identifying the thermal sensation (TS) levels also referred as actual mean vote (AMV) and thermal preferences by the occupants in the NV and air-conditioned (AC) classrooms of higher learning technical institutions in the warm and humid climatic region of Madurai. As the minimum age limit of the students in the institution starts at 18 years and above, the occupants are considered as adults. Hence, the literature studies for thermal comfort in school classrooms have not been reviewed in this study. The tolerance levels of senior level school students are more than kids in primary schools (Teli et al., 2015; de Dear et al., 2015). The significance of this study is that an adaptive comfort model for NV classrooms in higher learning technical institutions in Madurai region has been generated by considering the TSs of the occupants and measured climate data of the indoor spaces of the case study buildings. The findings of this study also revealed that the occupants felt more comfortable in NV classrooms than AC classrooms and showed tolerance to higher indoor temperature levels than predicted by American Society of Heating, Refrigerating and Air-Conditioning Engineers (ASHRAE) comfort levels with minimum adjustments. The implication of building design also played an important role in regulating the air movement and indoor temperature of the NV learning spaces. 


\section{Previous studies on thermal comfort and adaptive thermal comfort}

Thermal comfort is defined as the state of pleasantness felt by an individual in the absence of irritations or discomfort due to heat or cold (Givoni, 1981). The history of thermal comfort studies is supposed to have begun from 1936 by A.P. Gagge, who was the first to study the relationship between the body of a human and his surroundings and expressed the first principle of thermodynamics for the human body (Fabbri, 2015). Architect Givoni (1963) introduced "the index of thermal stress" in which he estimated the effect of climate on man. Following Givoni, architect Olgyay (1963) did an empirical study on the relationship between architectural form and its climate. Fanger (1967) studied the relationship between physical, psychological parameters and introduced the first thermal comfort equation to calculate the thermal perception of the human well-being.

Adaptive thermal comfort is the desire to feel thermally comfortable at a particular environment (both indoor and outdoor) and varies from person to person (Nicol, 2011). One person in a room may feel cold, whereas another person may feel comfortable with the environment. The basic concept of adaptive thermal comfort is related to human behaviour. In conditions of thermal discomfort, the occupants react and adapt to the circumstances by making themselves feel comfortable, for example, actions such as wearing lighter clothes in the summer, opening a window for air movement, switching on the fan, changing sitting posture (Humphreys, 2002). To achieve adaptive comfort, the NV space must have operable windows, no air conditioners and their activity levels must be near sedentary with a metabolic rate between 1.0 and 1.3 met. Over the past few decades, many researchers across the world have conducted thermal comfort studies in primary and secondary schools and can be achieved by the occupants at comparatively higher temperatures than the thermal comfort limits defined by ASHRAE 55-2017. The experiments conducted by them were based on subjects within climate chambers in the beginning and later on, conducted in actual field either NV or AC buildings such as offices, residential buildings and outdoor premises (Choyimanikandiyil, 2016). Adaptive approaches give varied TS results as it is based on the subjective behaviour of the occupants and their surrounding environment (Ricciardi and Buratti, 2012). Toe and Kubota (2013), in their study, predicted neutral temperature ranges of $24.9^{\circ} \mathrm{C}-31.2^{\circ} \mathrm{C}$ for hot and humid, $24.8^{\circ} \mathrm{C}-33.7^{\circ} \mathrm{C}$ for hot and dry and $19^{\circ} \mathrm{C}-24.7^{\circ} \mathrm{C}$ for moderate climates. They also concluded that hot and humid climatic regions necessitate their own adaptive comfort standards. Udrea et al. (2017) conducted a similar study in Romania and developed the first adaptive thermal comfort model for NV buildings in Romania. Alwetaishi (2016) made an extensive study on adaptive thermal comfort based on different building types and functions and stated that the function of the building has a significant effect on adaptive behaviour of the occupants. They also stated that adaptability of the occupants varies based on their activities, clothing and building design. An extensive study carried out by Hwang et al. (2006) at $10 \mathrm{NV}$ classrooms out of 36 classroms involving 944 students in Taiwan found that thermal neutrality took place at a higher temperature of $26.3^{\circ} \mathrm{C}$ than the thermal preferences that took place at $24.7^{\circ} \mathrm{C}$, proving that the neutral (adaptive) temperature is higher that the preferred temperature. In India, studies on adaptive comfort studies in NV and AC buildings have been carried out by researchers such as Indraganti et al. (2014), Mishra and Ramgopal (2015), Manu et al. (2016) and Jindal (2019). The indoor comfort temperatures for NV and AC modes of offices in the hot and humid climatic zones of south India derived by Indraganti et al. (2014) were found to be $28^{\circ} \mathrm{C}$ and $26.4^{\circ} \mathrm{C}$. Mishra and Ramgopal (2015) from their study derived thermal comfort ranges for students in $\mathrm{NV}$ classrooms of an institutional building located in the warm and humid climatic region of India between $24^{\circ} \mathrm{C}$ and $31^{\circ} \mathrm{C}$.
Adaptive thermal comfort model

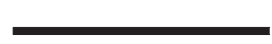




\section{Research methodology}

The thermal comfort evaluation method was carried out through two different approaches: a subjective and an objective survey. The subjective approach included assessment of occupants' thermal preferences and TS votes through questionnaire survey of ASHRAE seven-point scale. The survey was carried out in NV classrooms and AC classrooms situated in five isolated educational buildings co-located within the same microclimatic region. The details and specifications of the case study buildings are given in Figure 1. The data included 383 survey questionnaires from NV classrooms and 312 from AC classrooms and on-site measurements of interior and exterior weather conditions. Each questionnaire had 12 questions in two pages which were filled by the respondents (Figure A1). The respondents were asked to fill the questionnaire and hand it over in $30 \mathrm{~min}$. The major respondents of both NV and AC classrooms were students, whose age group ranges between 18-27 years. The clo value ranged between 0.5 and 0.7 clo. It was observed that there were no major variations in clothing among the individuals during both winter and summer seasons, as winters are mild in Madurai. The objective approach included field measurement of indoor and outdoor temperature and relative humidity levels using HTC Easy Log data loggers and air velocities using Lutron AM-4201 anemometer and indoor air quality using IAQ-Calc

Figure 1.

Overview of case studies taken for thermal comfort study

\begin{tabular}{|c|c|c|c|c|c|c|c|}
\hline $\begin{array}{l}\text { Building } \\
\text { code }\end{array}$ & Picture & $\begin{array}{l}\text { Building } \\
\text { type \& } \\
\text { Orientation }\end{array}$ & $\begin{array}{l}\text { No. of } \\
\text { stories }\end{array}$ & $\begin{array}{l}\text { Gross } \\
\text { Floor } \\
\text { area } \\
\text { (Sq.m) }\end{array}$ & $\begin{array}{l}\text { Avg. } \\
\text { people } \\
\text { /floor }\end{array}$ & $\begin{array}{l}\text { Mode } \\
\text { type }\end{array}$ & $\begin{array}{l}\text { Building } \\
\text { envelope } \\
\text { material } \\
\text { s }\end{array}$ \\
\hline Case Study 1 & 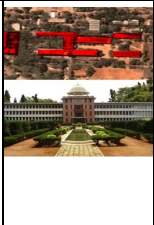 & $\begin{array}{l}\text { Educational } \\
\text { building \& } \\
\text { North-south }\end{array}$ & 3 & 20000 & 300 & MM & $\begin{array}{l}\text { Wall- } \\
\text { stone } \\
\text { Roof- } \\
\text { RCC } \\
\text { Floor- } \\
\text { Granite/ } \\
\text { cement/ } \\
\text { vinyl }\end{array}$ \\
\hline Case Study 2 & 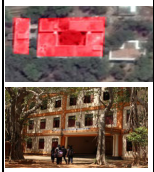 & $\begin{array}{l}\text { Educational } \\
\text { building \& } \\
\text { West-east }\end{array}$ & 2 & 4000 & 150 & MM & $\begin{array}{l}\text { Wall- } \\
\text { Brick } \\
\text { Roof- } \\
\text { RCC } \\
\text { Floor- } \\
\text { cement }\end{array}$ \\
\hline Case Study 3 & & $\begin{array}{l}\text { Educational } \\
\text { building \& } \\
\text { West-East }\end{array}$ & 4 & 6000 & 120 & $\mathrm{NV}$ & $\begin{array}{l}\text { Wall- } \\
\text { Brick } \\
\text { Roof- } \\
\text { RCC } \\
\text { Floor- } \\
\text { cement }\end{array}$ \\
\hline Case Study 4 & 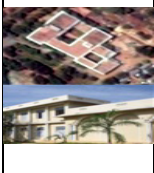 & $\begin{array}{l}\text { Educational } \\
\text { building \& } \\
\text { East-west }\end{array}$ & 2 & 5000 & 150 & $\mathrm{NV}$ & $\begin{array}{l}\text { Wall- } \\
\text { Brick } \\
\text { Roof- } \\
\text { RCC } \\
\text { Floor- } \\
\text { cement }\end{array}$ \\
\hline Case Study 5 & 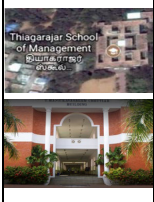 & $\begin{array}{l}\text { Educational } \\
\text { building \& } \\
\text { East-west }\end{array}$ & 2 & 6200 & 120 & MM & $\begin{array}{l}\text { Wall- } \\
\text { Brick } \\
\text { Roof- } \\
\text { RCC } \\
\text { Floor- } \\
\text { Granite/ } \\
\text { Tiles }\end{array}$ \\
\hline
\end{tabular}


7545. The outdoor data and indoor data were recorded for the months of March and April from 1 March 2016 to 30 April 2016, as the overheating period of Madurai lies between the months of March-September (Subhashini and Thirumaran, 2018), and also, the summer vacation begins by the last week of April and the odd semester commences by June first week. Hence, taking this into consideration, the field measurements and thermal comfort study were carried out in the months of March and April. The results of subjective survey were classified based on the questions asked as thermal sensation votes (TSV), thermal preference votes (TPVs) and thermal acceptability votes (TAVs) and tabulated into excel format for further analysis. The TSV or AMV recorded during comfort survey are compared with the predicted mean vote (PMV) -predicted percentage of dissatisfied (PPD) values derived from CBE/Berkley thermal comfort calculation tool (CBE/Berkley, 2013) to predict the variations between occupants' perception on thermal comfort and thermal comfort prediction according to ASHRAE Standard 55. Finally, the neutral temperature for Madurai was evaluated using the linear regression method correlating the recorded indoor temperature in the classrooms and 30-day running mean outdoor air temperature for the month of April 2016.

\section{Location and description of the case study buildings}

The case study buildings were identified from two higher learning institutions located nearby each other in the suburbs of Madurai. The climate of Madurai is classified as warm and humid according to ECBC (2006). The overview of the classrooms considered for study is given in Table 1. The details of the case study buildings are shown in Figure 1. The mode of ventilation is denoted as NV for naturally ventilated and MM for mixed mode as given in Figure 1. All the case study buildings were single storied, constructed of 9' thick brick masonry structure and had reinforced concrete flat roof with weatherproofing of about 150-200 mm thick, except the civil department lecture halls (lecture hall type IV given in Table 1) in which the walls were constructed of ashlar masonry. The NV classrooms had windows on both sides and either single or double banked. The window frames and doors in the NV classrooms were of steel. The window frames in AC classrooms were of wood with glass shutters. All the buildings surveyed had courtyards with aspect ratio 1:1 and 1:2. The outdoor environments of both the case study buildings are covered by dense trees and medium- and low-height shrubs.

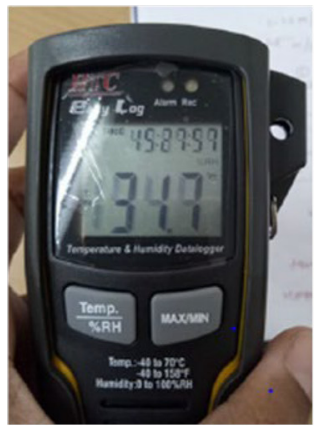

(a)

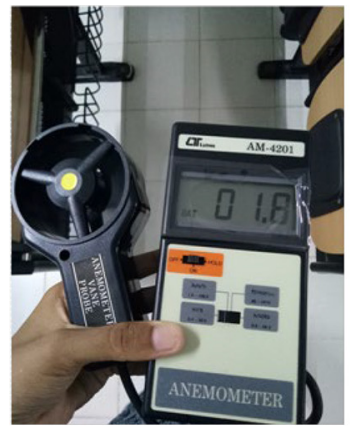

(b)

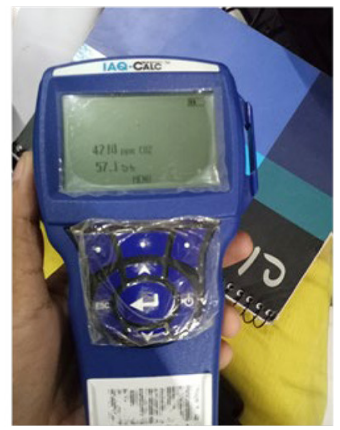

(c)
Adaptive thermal comfort model 


\section{Subjective survey method}

The respondents were asked to fill a thermal comfort survey questionnaire based on ASHRAE seven-point scale and return it back within an hour. There are three types of subjective responses that can be used to understand the comfort levels under non-uniform thermal conditions. They are defined as TSV or AMV, TAV and TPV. Thermal acceptability can be evaluated through a direct measurement system, which offers a wide range of acceptability than the sensation votes with the central three categories of the sevenpoint ASHRAE TS scale. It is usually in the form of question and answer. The subjects are asked to answer the questionnaire to determine whether at least $80 \%$ are satisfied with the thermal environment. Few examples of the questions that may be asked are as follows. Do you feel the thermal environment as acceptable? The answer will be yes or no. The relationship between TS and acceptability was first clarified by Fanger (1970) and then confirmed by Berglund (1979) through an experimental study. This study has tried to evaluate the AMV of the occupants for the indoor classroom environment during the overheating period.

\section{Subjective survey results}

The indoor operative temperatures of the $\mathrm{AC}$ classrooms were set between $24^{\circ} \mathrm{C}$ and $26^{\circ} \mathrm{C}$, and the indoor temperature in the NV classrooms ranged from $31.7^{\circ} \mathrm{C}$ to $33.5^{\circ} \mathrm{C}$ between 9:00 a.m. and 5.00 p.m. with outdoor 30-day mean temperature ranging from $28^{\circ} \mathrm{C}$ to $38.5^{\circ} \mathrm{C}$ in the month of April. The TS levels for both AC classrooms and NV classrooms were calculated using linear regression equation derived by Brager and de Dear (2000) and is expressed as follows:

(For centralised AC buildings):

$$
\mathrm{Ts}=0.51 \times \mathrm{T}_{\mathrm{op}}-11.96
$$

(For NV buildings) ( $\mathrm{T}_{\mathrm{op}}$ in):

$$
\mathrm{Ts}=0.27 \times \mathrm{T}_{\mathrm{op}}-6.65
$$

If the value of $T s=0$, then the temperature is assumed to be neutral using the above equations (1) and (2).

The TS levels for both AC classrooms and NV classrooms were calculated using equations (1) and (2), respectively, and the results are shown in Table 2. From the results, it is observed that the predicted TS values (Ts) were "neutral" at temperature ranges between

Table 1.

Overview of classrooms taken for thermal comfort

\begin{tabular}{|c|c|c|c|c|c|}
\hline S.no. & Name of classroom & Occupant capacity & Ventilation strategy & $\begin{array}{c}\text { Room size } \\
\mathrm{L} \times \mathrm{B}\end{array}$ & $\begin{array}{l}\text { Window size } \\
\text { Width } \times \text { height }\end{array}$ \\
\hline 1 & Studio type I & 40 & NV & $18 \mathrm{~m} \times 11 \mathrm{~m}$ & $1.35 \mathrm{~m} \times 1.35 \mathrm{~m}$ \\
\hline 2 & Studio type II & 40 & NV & $12 \mathrm{~m} \times 8 \mathrm{~m}$ & $1.35 \mathrm{~m} \times 1.35 \mathrm{~m}$ \\
\hline 3 & Studio type III & 40 & NV & $16 \mathrm{~m} \times 6 \mathrm{~m}$ & $1.35 \mathrm{~m} \times 1.35 \mathrm{~m}$ \\
\hline 4 & Lecture hall type I & 40 & NV & $9 \mathrm{~m} \times 6 \mathrm{~m}$ & $1.35 \mathrm{~m} \times 1.35 \mathrm{~m}$ \\
\hline 5 & Lecture hall type II & 80 & NV & $12.5 \mathrm{~m} \times 6.5 \mathrm{~m}$ & $1.35 \mathrm{~m} \times 1.35 \mathrm{~m}$ \\
\hline 6 & Lecture hall type III & 40 & $\mathrm{AC}$ & $9.7 \mathrm{~m} \times 7.3 \mathrm{~m}$ & $1.35 \mathrm{~m} \times 2.1 \mathrm{~m}$ \\
\hline 7 & Lecture hall type IV & 60 & NV & $12.5 \mathrm{~m} \times 9.5 \mathrm{~m}$ & $1.35 \mathrm{~m} \times 2.1 \mathrm{~m}$ \\
\hline 8 & Seminar hall I & 100 & NV & $16 \mathrm{~m} \times 9.5 \mathrm{~m}$ & $1.35 \mathrm{~m} \times 1.35 \mathrm{~m}$ \\
\hline 9 & Seminar hall II & 100 & $\mathrm{AC}$ & $12.1 \mathrm{~m} \times 7.3 \mathrm{~m}$ & $1.35 \mathrm{~m} \times 2.1 \mathrm{~m}$ \\
\hline
\end{tabular}
study 
$23.5^{\circ} \mathrm{C}$ and $25^{\circ} \mathrm{C}$ in $\mathrm{AC}$ classrooms and "warm" and "slightly warm" in NV classrooms (Table 2).

This shows that almost $80 \%$ in AC classrooms were satisfied when the temperature ranges were between $23.5^{\circ} \mathrm{C}$ and $25^{\circ} \mathrm{C}$; but in the subjective survey responses, it was also mentioned that during long continuous class hours in the afternoon, the students in $\mathrm{AC}$ classrooms felt more suffocating, and they could not concentrate on the classes. So, about $60 \%$ of the students were dissatisfied with the indoor classroom environment in AC classrooms. On the other hand, the AMV in the NV classrooms ranged from 0.6 to 2.0 according to ASHRAE seven-point scale [Figure 3(a)], indicating that almost $80 \%$ of the occupants felt comfortable with the indoor environment. This denotes the fact that students in NV classrooms were more adaptive and comfortable than students in AC classrooms. It was noticed the AMV in the NV classrooms differed based three main factors: the orientation and sizes of openings, shading devices and ventilation strategies. The students on NV classrooms with well-shaded windows and proper cross ventilation were more satisfied throughout the day during the summer month than those with single side openings and no shading devices. The students in NV classrooms showed more adaptive behaviour such as opening or closing the windows, using fans.

\section{Comparison between actual mean vote and predicted mean vote}

The AMV was compared with the PMV derived from the CBE/Berkley thermal comfort tool in the NV classrooms to evaluate the variance in thermal perception by the occupants with the PMV derived from ASHRAE standard 55, under the same indoor weather conditions. Figure 3(a) shows the regression plot for indoor temperature and AMV in the NV classrooms. Figure 3(b) shows the regression plot for indoor temperature and PMV in the NV classrooms.

\begin{tabular}{|c|c|c|c|c|c|c|}
\hline Time & 9.00 a.m. & 11.00 a.m. & 1.00 p.m. & 3.00 p.m. & 5.00 p.m. & \\
\hline $\begin{array}{l}\text { Indoor temp. }{ }^{\circ} \mathrm{C} \text { for } \mathrm{AC} \text { classrooms } \\
\mathrm{Ts}(\mathrm{AC})\end{array}$ & $\begin{array}{c}26 \\
1.3 \\
\text { (slightly warm) }\end{array}$ & $\begin{array}{c}24 \\
0.28 \\
\text { (neutral) }\end{array}$ & $\begin{array}{c}24 \\
0.28 \\
\text { (neutral) }\end{array}$ & $\begin{array}{c}23.5 \\
0.0 \\
\text { (neutral) }\end{array}$ & $\begin{array}{c}24 \\
0.28 \\
\text { (neutral) }\end{array}$ & $\begin{array}{l}\text { Table } 2 . \\
\text { Observed }\end{array}$ \\
\hline Indoor temp. ${ }^{\circ} \mathrm{C}$ in a NV classroom & 31.7 & 32.2 & 32.9 & 33.5 & 33.5 & temperature \\
\hline Ts(NV) & $\begin{array}{c}1.9 \\
\text { (slightly warm) }\end{array}$ & $\begin{array}{c}2.0 \\
\text { (warm) }\end{array}$ & $\begin{array}{c}2.2 \\
\text { (warm) }\end{array}$ & $\begin{array}{c}2.4 \\
\text { (warm) }\end{array}$ & $\begin{array}{c}2.4 \\
\text { (warm) }\end{array}$ & $\begin{array}{l}\text { measurements and } \\
\text { thermal sensations }\end{array}$ \\
\hline
\end{tabular}

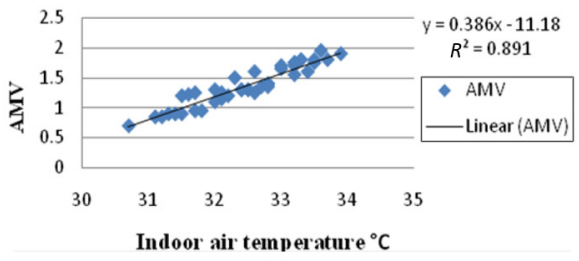

(a)

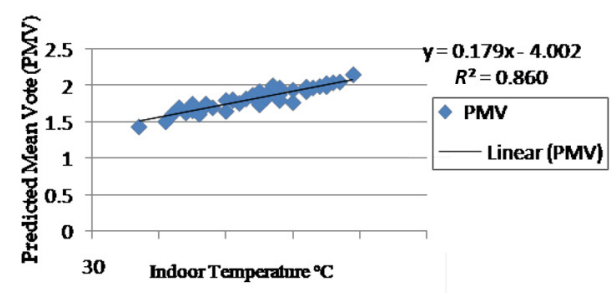

(b)
Figure 3. (a) Regression plot of AMV predicted by occupants in NV classrooms in summer; (b) regression plot of indoor temperature vs PMV calculated using CBE thermal comfort tool 
It is noticed that AMV is lower that the PMV for the same indoor temperature in summer in Figure 4(a). Thus, it shows that occupants in NV classrooms were adaptive to higher levels of indoor temperature than the PMV derived from the CBE/Berkeley comfort tool. To prove this, AMV and PMV were correlated in a regression chart, and the results revealed stronger correlation between the indoor temperature and TSVs given by occupants [Figure 4(a)]. Moreover, there was a drastic difference in AMV in different NV spaces in the same building based on their location in the building, percentage of openings, orientation of the windows and volume of the space, but all the values were lower the TSVs (AMV) derived from the occupants. The spaces in ground floor and on the northern, eastern and southern sides were cooler than the classrooms located on the western sides and floors with roof exposed to solar radiation.

The adaptive PMV (aPMV) model was developed by Yao et al. (2009) using the "Blackbox" theory for cool and warm conditions as it was found that PMV model is not appropriate for evaluating TS in NV spaces, particularly in tropical regions. The aPMV model describes that PMV overestimates the TS of occupants in warm places as the model fails to consider the psychological and adaptive nature of the occupants in NV buildings. The aPMV model is expressed as aPMV $=\operatorname{PMV} /(1+\lambda \times \mathrm{PMV})$, where $\lambda$ is the adaptive coefficient value. The $\lambda$ value was derived as 0.293 for warm conditions, from field study carried out in Chongqing University, China. Yao et al. (2009) states that the aPMV model-based PMV method can be applicable in varied building types with consideration of the local climate, sociocultural and behavioural aspects, etc., and also be used to study neutral temperature set points, one of the critical factor that affects the energy consumption in buildings.

The equation for the model is expressed as follows:

$$
a \mathrm{PMV}=\frac{P M V}{(1+0.293 \times P M V)}(\text { Warm conditions })
$$

The aPMV for the NV classrooms in Madurai region (warm conditions) was derived using equation (3), and Figure 4(b) shows the comparative regression analysis of AMV, PMV and aPMV. It is shown that the aPMV values are lower than PMV [Figure 4(b)]. This shows that the occupants' feel less hot than the PMV index in this scenario.

\section{Assessment of neutral temperature for Madurai}

\subsection{Derivation of neutral temperature using adaptive comfort model developed by Manu} et al., 2015

The Centre for Advanced Research in Building Science and Energy at CEPT University has developed an Indian Model for Adaptive (Thermal) Comfort (IMAC) 2014 with an aim to use energy in buildings while maintaining the comfort levels of the occupants to suit the Indian

Figure 4.

(a) PMV and AMV regression plot; (b) AMV, PMV and aPMV regression plot

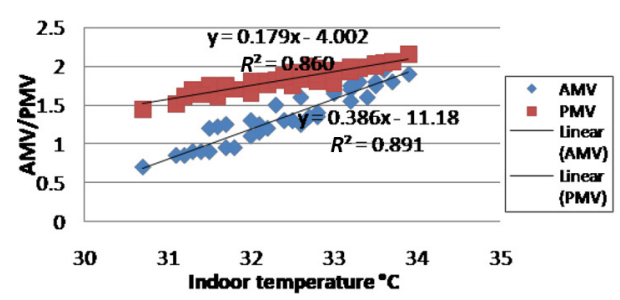

(a)

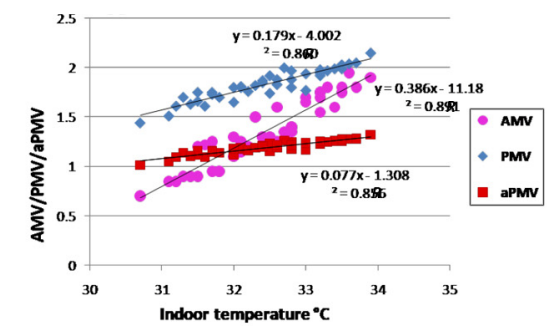

(b) 
climatic context. The IMAC study for neutral temperatures and acceptability limits was carried out in NV, AC and MM offices in India at different climatic zones by Manu et al. (2016), and the results indicated that thermal adaptability was more in MM offices than AC offices but less than NV offices.

The adaptive comfort model developed by Manu et al. (2016) can be used to calculate the neutral temperature of NV buildings with the 30-day running mean outdoor air temperature ranging from $13^{\circ} \mathrm{C}$ to $38.5^{\circ} \mathrm{C}$ and is expressed as in equation (4) below:

$$
\text { Tcomf }=0.28 \times \text { Tout }+17.9
$$

where Tcomf is the neutral temperature or indoor operative temperature $\left({ }^{\circ} \mathrm{C}\right)$, and $\mathrm{T}_{\text {out }}$. According to climate data of Madurai, the overheating period lies between the months of March to September, with April being the hottest month of the year (www.tn.gov.in/deptst/ climateandrainfall.pdf). The lowest temperature in a year ranges from $18^{\circ} \mathrm{C}$ to $21^{\circ} \mathrm{C}$, and highest temperature ranges from $38^{\circ} \mathrm{C}$ to $41^{\circ} \mathrm{C}$ (www.meteoblue.com).

\subsection{Derivation of neutral temperature using linear regression method}

The neutral temperature model for NV classrooms of educational buildings in Madurai was developed by plotting the linear regression from the recorded outdoor and indoor temperature data in the NV classrooms of the case study buildings (Figure 5). This study has used linear regression method to derive neutral temperature of Madurai.

The neutral temperature model derived for the climate of Madurai is expressed in equation (5).

The adaptive neutral temperature equation for Madurai is given as:

$$
\mathrm{aTn}=0.28 \times \mathrm{T}_{\text {out }}+23.07
$$

Using the equation (5), the neutral temperatures for each month in a year were derived in the range between $29.0^{\circ} \mathrm{C}$ and $33.6^{\circ} \mathrm{C}$ and expressed in Table 3 . A comparison of neutral temperature using equations (4) and (5) is also expressed in Table 3. According to adaptive model developed by Manu et al. (2016) and expressed in equation (4), the neutral temperature of $\mathrm{NV}$ classrooms in Madurai ranges from $23.9^{\circ} \mathrm{C}$ to $28.5^{\circ} \mathrm{C}$, whereas using equation (5), developed by the current study, the neutral temperature ranges between $29.0^{\circ} \mathrm{C}$ and $33.6^{\circ} \mathrm{C}$.

The results have been validated by comparing with the neutral temperature ranges of Thiruchirapalli (also called Trichy). The Indian Society of Heating, Refrigerating and Air Conditioning Engineers has provided temperature data of only two cities in Tamil Nadu; Chennai and Thiruchirapalli. Due to the unavailability of proper models and long-term weather data files for other cities such as Madurai, the climate data of Madurai is not

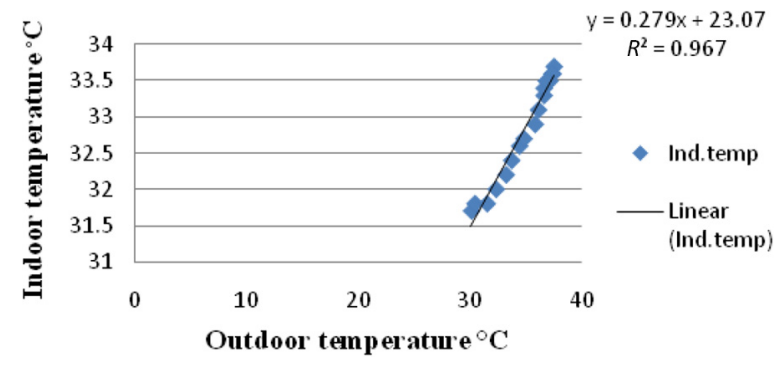

Figure 5. Regression plot for neutral temperature of Madurai 


\section{$\mathrm{OHI}$}

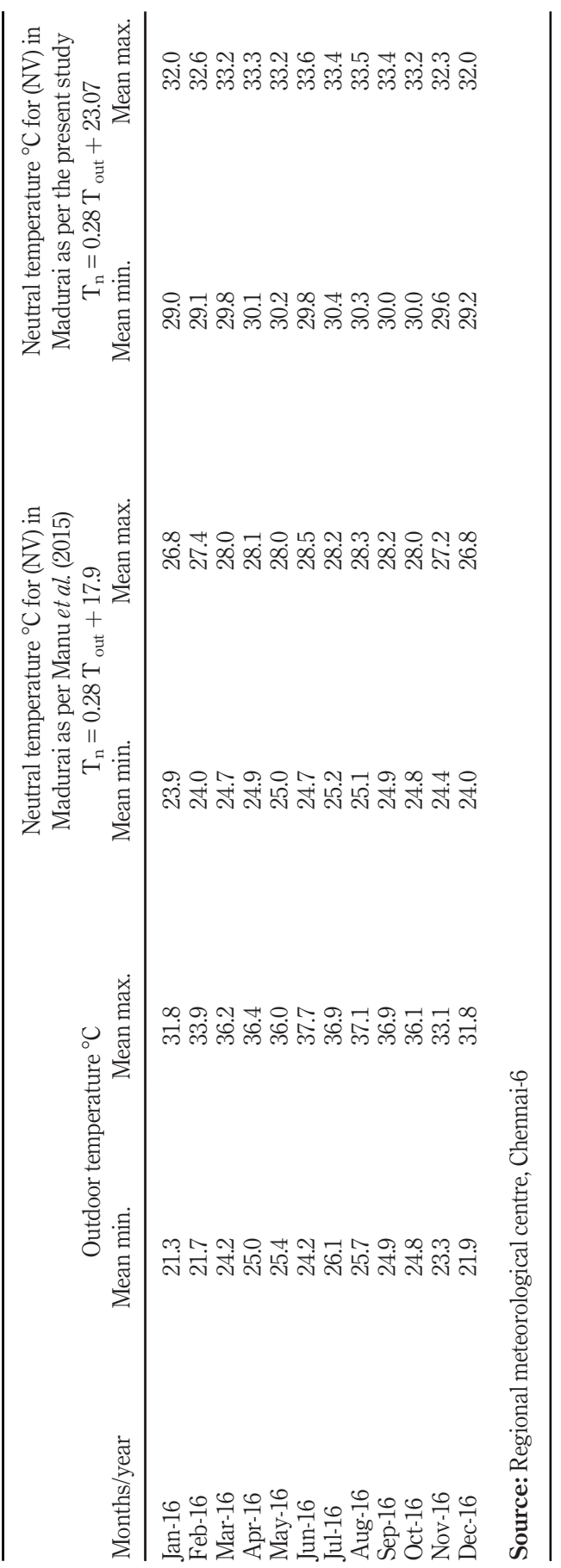

Table 3.

Adaptive neutral temperature for Madurai 
available in energy plus weather (EPW) format. Hence, the neutral temperature of Trichy derived from the IMAC thermal comfort tool (Figure 6) was considered for the validation of the results from the current study, as Trichy is located close to Madurai at a distance of about $132 \mathrm{~km}$ and falls under the same climatic zone. According to the data shown in Figure 6, the neutral temperatures with $90 \%$ acceptability for $\mathrm{NV}$ buildings in Thiruchirapalli are between $24.27^{\circ} \mathrm{C}$ and $32.43^{\circ} \mathrm{C}$ in the months of January and May. This shows that the upper limits of neutral temperature is slightly closer to the maximum neutral temperature of Trichy, but the lower levels derived from the adaptive model [equation (5)] for Madurai are nearly $5^{\circ} \mathrm{C}$ higher than Trichy. In Figure 4(b) it can be seen that the aPMV levels are lower than AMV and PMV in the naturally ventilated classrooms of Madurai, thereby supporting the fact that occupants in Madurai are more adaptive to higher indoor temperature levels with minimum adjustments. Thus, this study proves that although both Trichy and Madurai falls under warm and humid climatic regions, there are various other factors such as microclimatic conditions, vegetation, building design, building materials and adaptive behaviour of the occupants that influence the thermal comfort of the indoor spaces.

\section{Conclusions}

The thermal comfort study was carried out in NV and AC classrooms of two educational institutions in Madurai region. It was evident from this study that the students felt more fresh and comfortable in the NV learning spaces than the AC classrooms. Based on the observations of field study and questionnaire survey, it was found that the rise in $\mathrm{CO}_{2}$ levels after few hours in AC classrooms made the students more sluggish and difficult to concentrate during long lecture hours. The adaptive neutral temperature (aTn) for NV buildings in Madurai ranges from $29^{\circ} \mathrm{C}$ to $34^{\circ} \mathrm{C}$. This shows that occupants in the NV classrooms of the higher learning institutions in the warm and humid climatic region of

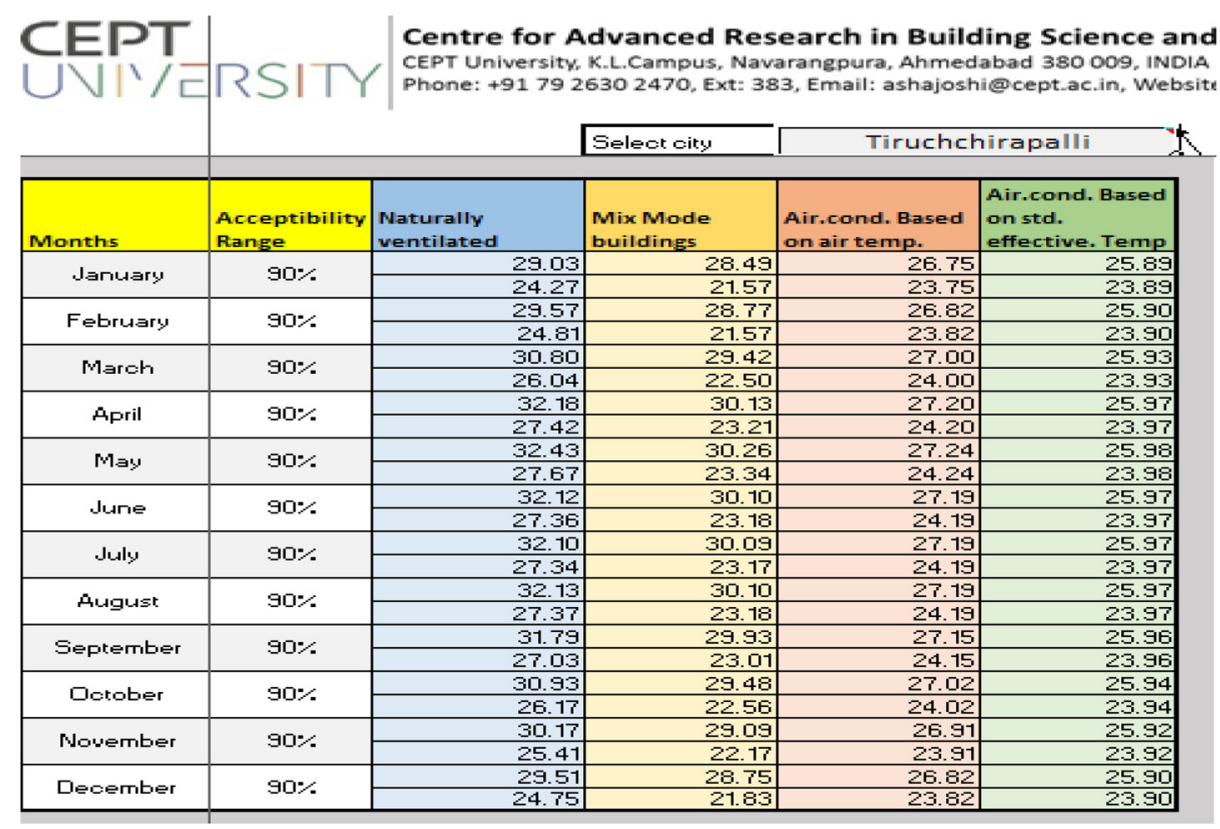

Figure 6. Acceptability range of temperature different building types for Tiruchirapalli 
Madurai can adapt well to higher indoor temperature levels than predicted by ASHRAE comfort levels with minimum adjustments. This study concludes that the neutral temperature model (aTn) derived for Madurai in this study can be used to derive the adaptive neutral temperature of regions with 30-day mean outdoor temperatures ranging from $18^{\circ} \mathrm{C}$ to $40^{\circ} \mathrm{C}$. This study also showed that the students preferred more openness and air movement and connection between nature rather than enclosed AC spaces. This study provides a strong base for architects to design educational buildings that are more responsive to the natural environment and also its occupants. Architects such as Charles Correa, B.V. Doshi, Laurie Baker, F. L. Wright and Hasan Fathy are few inspiring pioneers who have designed environment and occupant friendly architectural examples for us to get inspired and follow.

\section{References}

Alwetaishi, M.S. (2016), "Impact of building function on thermal comfort: a review paper", American Journal of Engineering and Applied Sciences, Vol. 9 No. 4, pp. 928-945.

Berglund, L.G. (1979), "Thermal acceptability”, ASHRAE Transactions, Vol. 85 No. 2, pp. 825-834.

Brager, G.S. and de Dear, R.J. (2000), "A standard for natural ventilation”, ASHRAE Journal, Vol. 42 No. 10, pp. 21-28.

Choyimanikandiyil, K. (2016), "Critical gap in research on adaptive thermal comfort of children in primary school buildings", International Journal of Advances in Mechanical and Civil Engineering, Vol. 3 No. 2.

de Dear, R., Kim, J., Candido, C. and Deuble, M. (2015), "Adaptive thermal comfort in Australian school classrooms", Building Research and Information, Vol. 43 No. 3.

ECBC (2006), Energy Conservation Building Code (ECBC) User Guide, Bureau of Energy Efficiency, New Delhi.

Energy statistics (2017), Central Statistics Office, Ministry of Statistics and Programme Implementation (MOSPI), Government of India.

Fabbri, K. (2015), "A brief history of thermal comfort: from effective temperature to adaptive thermal comfort, chapter 2", Indoor Thermal Comfort Perception, Springer International Publishing, Switzerland. doi: 10.1007/978-3-319-18651-1_2.

Fanger, P.O. (1967), "Calculations of thermal comfort: introduction of a basic comfort equation", ASHRAE Trans, Vol. 73, pp. 1-4.

Fanger, P.O. (1970), Thermal Comfort Analysis and Applications in Environmental Engineering. Copenhagen, Danish Technical Press.

Givoni, B. (1963), "The effect of climate on man: development of a new thermal index. Research report to UNESCO", Building Research Station, Technion, Haifa.

Givoni, B. (1981), Man, Climate and Architecture, Van Nostrand Reinhold, New York, NY.

Humphreys, M.A. (2002), "Adaptive thermal comfort and sustainable thermal standards for buildings”, Energy and Buildings, Vol. 34 No. 6, pp. 563-572.

Hwang, R.L., Lin, T.P. and Kuo, N.J. (2006), "Field experiments on thermal comfort in campus classrooms in Taiwan", Energy and Buildings, Vol. 38 No. 1, pp. 53-62.

Indraganti, M., Ooka, R., Rijal, H.B. and Brager, G.S. (2014), "Adaptive model of thermal comfort for offices in hot and humid climates of India", Building and Environment, Vol. 74, pp. 39-53.

Jindal, A. (2019), "Investigation and analysis of thermal comfort in naturally ventilated secondary school classrooms in the composite climate of India", Architectural Science Review, Vol. 62 No. 6, pp. 466-484. 
Manu, S., Shukla, Y., Rawal, R., Leena, E.T. and de Dear, R. (2016), "Field studies of thermal comfort across multiple climate zones for the subcontinent. India model for adaptive comfort (IMAC)", Building and Environment, Vol. 98, pp. 55-70.

Mishra, A.K. and Ramgopal, M.A. (2015), "Thermal comfort field study of naturally ventilated classrooms in Kharagpur, India", Building and Environment, Vol. 92, pp. 396-406.

NIC (2009), "The National Intelligence Council (NIC) special report", The Impact of Climate Change to 2030: Geopolitical Implications, India.

Nicol, J.F. (2011), “Adaptive comfort”, Building Research and Information, Vol. 39 No. 2, pp. 105-107.

Olgyay, V. (1963), Design with Climate: bioclimatic Approach to Architectural Regionalism, Princeton University Press, Princeton.

Ricciardi, P. and Buratti, C. (2012), "Thermal comfort in open plan offices in Northern Italy: an adaptive approach", Building and Environment, Vol. 56, pp. 314-320.

Subhashini, S. and Thirumaran, K. (2018), "A passive design solution to enhance thermal comfort in an educational building in the warm humid climatic zone of Madurai", Journal of Building Engineering, Vol. 18, pp. 395-407.

Teli, D., James, P.A.B. and Jentsch, M.F. (2015), "Investigating the principal adaptive comfort relationships for young children”, Building Research and Information, Vol. 43 No. 3, pp. 371-382.

The Intergovernmental Panel on Climate Change (IPCC) (2011), "Climate: observations, projections and impacts - India. A report by the met office (UK)", available at: www.indiawaterportal.org/ articles/climate-observations-projections-and-impacts-india-report-met-office-uk

Toe, D.H.C. and Kubota, T. (2013), "Development of an adaptive thermal comfortequation for naturally ventilated buildings in hot-humid climates using ASHRAE RP-884 database", Frontiers of Architectural Research, Vol. 2 No. 3, pp. 278-291.

Udrea, L., Croitoru, C., Nastase, I., Crutescu, R. and Badescu, V. (2017), "First adaptive thermal comfort equation for naturally ventilated buildings in Bucharest, Romania", International Journal of Ventilation, Vol. 17 No. 3.

Yao, R., Li, B. and Liu, J. (2009), "A theoretical adaptive model of thermal comfort-adaptive predicted mean vote (aPMV)", Building and Environment, Vol. 44 No. 10, pp. 2089-2096.

Zomorodian, Z.S., Tahsildoost, M. and Hafezi, M. (2016), "Thermal comfort in educational buildings: a review article", Renewable and Sustainable Energy Reviews, Vol. 59, pp. 895-906.

\section{Further reading}

ANSI/ASHRAE Standard 55-2017 (2017), Thermal Environmental Conditions for Human Occupancy, American Society of Heating, Refrigerating and Air-Conditioning Engineers, Atlanta, GA.

de Dear, R.J. and Brager, G.S. (1998), "Developing an adaptive model of thermal comfort and preference”, ASHRAE Transactions, Vol. 104 No. Part 1, pp. 145-167.

de Dear, R.J., Brager, G. and Cooper, D. (1997), Developing an Adaptive Model of Thermal Comfort and Preference. Final Report on ASHRAE RP-884, Macquarie University, Sydney.

Hoyt, T., Schiavon, S., Tartarini, F., Cheung, T., Steinfeld, K., Piccioli, A. and Moon, D. (2019), CBE Thermal Comfort Tool, Center for the Built Environment, University of CA Berkeley.

Humphreys, M.A. and Nicol, J.F. (1998), "Understanding the adaptive approach to thermal comfort", International Journal of ASHRAE Transactions, Vol. 104 No. 1, pp. 991-1004.

ISHRAE (2015), "Position paper on indoor environmental quality", available at: www.ishrae.in/images/ ISHRAE-Position-Paper-Indoor-Environmental-Quality.pdf 


\section{THERMAL COMFORT OUESTIONNAIRE FOR HIGHER LEARNING EDUCATIONAL}

\section{BUILDINGS}

\section{PERSONAL DATA}

1) Name:

2) Age:

3) Gender: MALE $\square$ FEMALE

4) Height (in cm):

5) Weight (in $\mathrm{Kg})$ :

6) Location in classroom:

Do you sit near the window? YES $\square$ NO

7) How many hours do you spent in classrooms per day? :

II. THERMAL COMFORT SURVEY:

8) How do you feel at this moment? :

(What you sense)

9) I would prefer the classroom

\begin{tabular}{|l|l|l|l|}
\hline \multirow{2}{*}{$\begin{array}{l}\text { Thermal } \\
\text { Sensations }\end{array}$} & \multicolumn{3}{|c|}{ Timings } \\
\cline { 2 - 4 } & $\begin{array}{l}9.00 \text { am- } \\
11.00 \mathrm{am}\end{array}$ & $\begin{array}{l}11.00 \mathrm{am}- \\
1.00 \mathrm{pm}\end{array}$ & $\begin{array}{l}2.00 \mathrm{pm}- \\
4.30 \mathrm{pm}\end{array}$ \\
\hline (3) Hot & & & \\
\hline (2) Warm & & & \\
\hline $\begin{array}{l}\text { (0) Slightly } \\
\text { warm }\end{array}$ & & & \\
\hline (0) Neutral & & & \\
\hline (-1) Slightly cool & & & \\
\hline (-2) Cool & & & \\
\hline (-3) Cold & & & \\
\hline
\end{tabular}
temperature to be:

Figure A1.

Thermal comfort questionnaire

\begin{tabular}{|l|l|l|l|}
\hline \multirow{2}{*}{$\begin{array}{l}\text { Thermal } \\
\text { preferences }\end{array}$} & \multicolumn{3}{|c|}{ Timings } \\
\cline { 2 - 4 } & $\begin{array}{l}9.00 \mathrm{am}- \\
11.00 \mathrm{am}\end{array}$ & $\begin{array}{l}11.00 \mathrm{am}- \\
1.00 \mathrm{pm}\end{array}$ & $\begin{array}{l}2.00 \mathrm{pm}- \\
4.30 \mathrm{pm}\end{array}$ \\
\hline (3) A lot warmer & & & \\
\hline (2) Warmer & & & \\
\hline (1) A bit warmer & & & \\
\hline (1) No change & & & \\
\hline (-1) A bit colder & & & \\
\hline (-2) colder & & & \\
\hline (-3) A lot colder & & & \\
\hline
\end{tabular}

(continued) 
10) Do you feel fresh air at the moment?

Adaptive thermal

\begin{tabular}{|c|c|c|}
\hline 9.00 am-11.00am & $11.00 \mathrm{am}-1.00 \mathrm{pm}$ & $2.00 \mathrm{pm}-\mathbf{4 . 3 0} \mathrm{pm}$ \\
\hline Yes/No & Yes/No & Yes/No \\
\hline
\end{tabular}

11) How do feel the air movement at present?

\begin{tabular}{|l|l|l|l|}
\hline \multirow{2}{*}{$\begin{array}{l}\text { Sensation of air } \\
\text { movement }\end{array}$} & \multicolumn{3}{|c|}{ Timings } \\
\hline & $\begin{array}{l}9.00 \mathrm{am}- \\
11.00 \mathrm{am}\end{array}$ & $\begin{array}{l}11.00 \mathrm{am}- \\
1.00 \mathrm{pm}\end{array}$ & $\begin{array}{l}2.00 \mathrm{pm}- \\
4.30 \mathrm{pm}\end{array}$ \\
\hline (3) Too still & & & \\
\hline (2) Still & & & \\
\hline (1) Slightly still & & & \\
\hline (0)No change & & & \\
\hline (-1) Slightly Breezy & & & \\
\hline (-2) Breezy & & & \\
\hline (-3) Too breezy & & & \\
\hline
\end{tabular}

12) How do feel the moisture in air at present?

\begin{tabular}{|l|l|l|l|}
\hline \multirow{2}{*}{$\begin{array}{l}\text { Sensation of } \\
\text { moisture in air }\end{array}$} & \multicolumn{3}{|c|}{ Timings } \\
\cline { 2 - 4 } & $\begin{array}{l}9.00 \mathrm{am}- \\
11.00 \mathrm{am}\end{array}$ & $\begin{array}{l}11.00 \mathrm{am}- \\
1.00 \mathrm{pm}\end{array}$ & $\begin{array}{l}2.00 \mathrm{pm}- \\
4.30 \mathrm{pm}\end{array}$ \\
\hline (3) Too dry & & & \\
\hline (2)Dry & & & \\
\hline (1) Slightly dry & & & \\
\hline (0)No change & & & \\
\hline (-1)Slightly humid & & & \\
\hline (-2) Humid & & & \\
\hline (-3) Too humid & & & \\
\hline
\end{tabular}

Figure A1.

Corresponding author

Subhashini S. can be contacted at: ssarch@tce.edu

For instructions on how to order reprints of this article, please visit our website: www.emeraldgrouppublishing.com/licensing/reprints.htm

Or contact us for further details: permissions@emeraldinsight.com 


\section{University Library}

\section{- M M N E R VA A gateway to Melbourne's research publications}

Minerva Access is the Institutional Repository of The University of Melbourne

Author/s:

Subhashini, S;Kesavaperumal, T;Noguchi, M

Title:

An adaptive thermal comfort model for naturally ventilated classrooms of technical institutions in Madurai

Date:

2021-11-22

Citation:

Subhashini, S., Kesavaperumal, T. \& Noguchi, M. (2021). An adaptive thermal comfort model for naturally ventilated classrooms of technical institutions in Madurai. Open House International, 46 (4), pp.682-696. https://doi.org/10.1108/OHI-03-2021-0075.

Persistent Link:

http://hdl.handle.net/11343/278737 